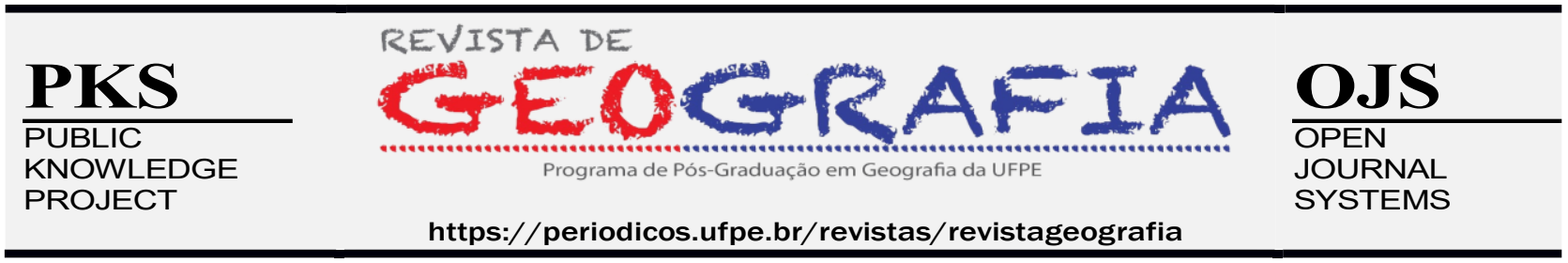

\title{
ANÁLISE DAS RELAÇÕES ECONÔMICAS ENTRE ALAGOAS E CHINA NO PERÍODO 2003-2019
}

\author{
Bruno Bianchi Gonçalves da Silva ${ }^{1}$, Domingos Sávio Corrêa ${ }^{2}$
}

\begin{abstract}
${ }^{1}$ Mestre em Geografia pela Universidade Federal de Alagoas. E-mail:bruno_bianchi1@hotmail.com, https://orcid.org/0000-0002-0918-0314

${ }^{2}$ Doutor em Geografia, professor da Universidade Federal de Alagoas. E-mail: domingos.correa@igdema.ufal.br, https://orcid.org/0000-0003-0320-3666
\end{abstract}

Artigo recebido em 29/04/2021 e aceito em 04/10/2021

\begin{abstract}
RESUMO
Nas duas últimas décadas a China alcançou o posto de segunda maior potência econômica mundial e principal parceiro comercial do Brasil, comandando a balança comercial de diversos estados brasileiros e estimulando a busca por investimento chinês em seus territórios. O objetivo deste artigo é analisar a dinâmica das relações econômicas entre o estado de Alagoas e a China no período 2003 a 2019, considerando as repercussões na economia alagoana e sua característica. $\mathrm{O}$ resultado apontou rápido crescimento da participação chinesa na importação de Alagoas, em reflexo ao aumento do poder de compra da população até meados da última década. O ritmo de crescimento não foi acompanhado pela exportação, diferenciando a dinâmica em Alagoas dos estados do Centro-Oeste.
\end{abstract}

Palavras-chave: Importação; Exportação; Alagoas; China.

\section{ANALYSIS OF ECONOMIC RELATIONS BETWEEN ALAGOAS AND CHINA IN THE PERIOD 2003-2019}

\begin{abstract}
In the last two decades, China has reached the position of the second largest economic power in the world and the main trading partner of Brazil, commanding the trade balance of several brazilian states and stimulating the search for chinese investment in their territories. The objective of this article is to analyze the dynamics of economic relations between the state of Alagoas and China in the period 2003 to 2019, considering the repercussions on the economy of Alagoas and its characteristics. The result showed a rapid growth in chinese participation in imports from Alagoas, reflecting the increase in the purchasing power of the population until the middle of the last decade. The pace of growth was not accompanied by exports, differentiating the dynamics in Alagoas from the states of the Midwest.
\end{abstract}

Keywords: Import; Export; Alagoas; China. 


\section{INTRODUÇÃO}

Há poucos anos a China era vista como um país atrasado, de economia agrária e uma indústria que através da pirataria produzia produtos de baixa qualidade. Atualmente, disputa a primazia tecnológica com os Estados Unidos, maior potência econômica mundial, e tem consolidado o Leste Asiático como o novo centro dinâmico mundial, antes comandado apenas por Japão e Coreia do Sul.

O atual patamar de desenvolvimento das forças produtivas que a China tem alcançado não é fortuito. Seguindo a esteira do desenvolvimento econômico pleno, Chang (2004) ressalta que cada potência econômica mundial adotou a própria estratégia de desenvolvimento, envolvendo muitas vezes, modificações de âmbito econômico, político e institucional.

Diferente das tradicionais potências econômicas [Inglaterra, Estados Unidos, Alemanha e Japão], o desenvolvimento chinês se deu em bases socialistas, desde a proclamação da República Popular da China, em 1949, sob a liderança de Mao Tsé-Tung. A via chinesa de desenvolvimento é marcada pelo mercado e planejamento, através do Estado promovendo arranjos e rearranjos entre as atividades privadas e estatais, caracterizando o 'socialismo de mercado' chinês (CHANG, 2004; JABBOUR, 2010).

No âmbito das reformas institucionais, a Reforma de 1978 transformou a economia centralmente planificada numa economia de mercado, sem abandonar o papel estratégico do setor estatal, além de instituir dois sistemas de preços [preço de mercado e preço administrado pelo Estado] protegendo o país das oscilações da economia mundial. Enquanto a década de 1980 é marcada pela criação das Zonas Econômicas Especiais, preparando o território chinês para a modernização, na década de 1990, ocorrem fusões e aquisições de pequenas empresas estatais, visando a competitividade e incorporação das inovações, culminando no surgimento de 149 conglomerados estatais, atuantes inclusive no setor exportador (JABBOUR, 2019).

A expansão da exportação chinesa foi impulsionada inicialmente pelo setor manufatureiro de trabalho intensivo. À medida que o país incorporava tecnologia, aumentava a eficiência e reduzia custos no setor capital intensivo, que aliado a desvalorização cambial, tornou mais competitivo os manufaturados de maior valor agregado. O início do século XXI representa para China a transição da fase de incorporação tecnológica para a fase de desenvolvimento tecnológico. Tornando-se candidata a liderança da Terceira Revolução Industrial e rival geopolítica e econômica dos Estados Unidos, posição ocupada no século XX por URSS e Japão (MAMIGONIAN, 2018; JABBOUR, 2019).

A pauta de exportação e importação chinesa demonstra esse feito. Nos anos 1990, seus principais produtos eram intensivos em trabalho como têxteis, vestuário e calçados, paralelo a isso, 
houve crescente participação de máquinas e eletrônicos, saltando de 22\% em 1995 para 47\% das exportações em 2007. Já no lado das importações, os produtos capitais intensivos como fibras sintéticas, químicos e aço representavam $24 \%$ do total importado em 2003 , enquanto que nos últimos anos, recursos naturais e minerais representam cerca de $34 \%$ do total importado. Alterações que permitiram a China obter sucessivos superávits comerciais, inclusive com os Estados Unidos que, devido ao crescimento da dívida pública e déficit comercial, vê sua liderança econômica mundial ameaçada pelo avanço chinês (MAMIGONIAN, 2018; JABBOUR, 2019).

Em 2012, a China se tornou o maior trader [exportação e importação] do mundo. A crescente participação e relevância no comércio mundial e o vigoroso desenvolvimento econômico da China tem reorientado as estratégias de crescimento econômico do Brasil, buscando maior aproximação nas duas últimas décadas, principalmente após a criação dos BRICS, em 2006, e da China ter se tornado nosso maior parceiro comercial em 2009 (BECARD, 2011; JABBOUR, 2019).

Acompanhando a nova conjuntura do século XXI, a balança comercial do estado de Alagoas passa a registrar fluxo comercial com a China e o rápido crescimento da participação, principalmente através das importações, quando o país se torna o principal parceiro comercial do estado na última década. A posição de destaque na balança comercial e o status da China de grande exportadora de capitais, com investimentos em diversas regiões do planeta, tem repercutido na economia alagoana e sua esfera política, onde tem estimulado a busca por investimentos chineses em anos recentes.

Diante disso, o artigo tem como objetivo analisar a dinâmica das relações econômicas entre o estado de Alagoas e a China no período 2003 a 2019, considerando as repercussões na economia alagoana e sua característica. Considerando tais aspectos, busca não se limitar a elementos quantitativos, ligados a balança comercial.

A pesquisa bibliográfica é baseada principalmente em autores que estudam o desenvolvimento econômico e social da China, destacando Jabbour (2010; 2019) e Mamigonian (2018), que trazem uma visão de processo a partir da Geografia Econômica. Em Chang (2004), analisando a estratégia de desenvolvimento das maiores potências econômicas, reforça a análise do desenvolvimento planejado da China e desmistifica a condução da economia chinesa pela mão invisível do mercado, argumento tão propalado no ocidente. Sobre a economia do estado de Alagoas, Carvalho $(2019 ; 2020)$ com diversos estudos a nível estadual, aborda as particularidades da economia alagoana.

O recorte temporal entre os anos 2003 a 2019 abrange o primeiro ano de fluxo comercial direto Alagoas-China, registrado no banco de dados do Ministério da Economia, e o ano que antecede os impactos comerciais causados pela pandemia de Covid-19. A escolha do recorte temporal se 
justifica por abranger inclusive os períodos de crescimento e recessão da economia estadual, inerentes a dinâmica econômica nacional.

O levantamento estatístico é oriundo do banco de dados de órgãos oficiais e associações comerciais, como: o Instituto Brasileiro de Geografia e Estatística - IBGE; Ministério de Economia; Secretaria de Estado do Planejamento, Gestão e Patrimônio - Seplag/AL; e Confederação Nacional da Indústria - CNI. Os dados do comércio de exportação e importação foram extraídos do sistema Comex Stat versão 2.0.3 do Ministério da Economia. A listagem dos produtos utilizou como parâmetro o Sistema Harmonizado - SH, sistema único mundial de designação e codificação de mercadorias.

A espacialização dos dados de exportação e importação por municípios de Alagoas utilizou o software de geoprocessamento QGIS versão 3.10.11. A categorização dos produtos por intensidade tecnológica utilizou a classificação da Organização para a Cooperação e Desenvolvimento Econômico - OCDE, em Rueda e Verger (2016), onde categorizaram os produtos em cinco níveis de intensidade tecnológica.

A seção resultados e discussões deste artigo está dividida em quatro itens. O primeiro item, faz uma breve análise da balança comercial alagoana com a China, da característica econômica de Alagoas e do perfil socioeconômico do estado no contexto regional. O segundo e terceiro itens tratam da exportação e importação alagoana com a China, destacando a participação do país no valor da exportação e importação do estado, principais produtos exportados e importados por Alagoas com destino/origem chinesa e a participação dos municípios alagoanos no comércio bilateral. Além disso, estes itens atrelam as exportações e importações ao dinamismo da economia estadual. Por fim, o quarto item destaca os principais investimentos chineses no estado nos últimos anos e a busca por novos investimentos.

\section{A RELAÇÃO ECONÔMICA ENTRE ALAGOAS E CHINA}

Alagoas é um estado de pequenas dimensões territoriais com perfil socioeconômico discreto se comparado ao contexto nacional e regional. Possui a terceira menor população do Nordeste, predominantemente jovem, onde os habitantes com idade entre 0 a 39 anos representam $72 \%$ da população do estado. A urbanização é um fato relativamente recente no estado, apenas na passagem da década de 1980 para 1990, a população urbana se tornou majoritária (IBGE, 2010).

Assim como a população, o PIB estadual é o terceiro menor do Nordeste. De acordo com os últimos dados consolidados, em 2018, o PIB alagoano foi de R \$ 54,4 bilhões. Para efeito de comparação, o PIB do estado vizinho, Pernambuco, foi de R\$ 186,3 bilhões no mesmo ano, mais de 
três vezes superior à economia de Alagoas, e a segunda maior economia da região. A agropecuária [cana-de-açúcar e pecuária leiteira] e comércio e serviços comandam a economia do estado. Apesar de extremamente relevante no dinamismo da economia, o mercado consumidor de Alagoas é estreito. Considerando a população em idade de trabalhar, em 2016, 29\% não tinham rendimento e 48\% recebiam até dois salários mínimos (IBGE, 2018; CARVALHO, 2020).

Diferente de alguns estados brasileiros, o fluxo direto de mercadorias entre Alagoas e China iniciou apenas no século XXI, logo após a entrada da China na OMC em 2001. O crescimento registrado em anos subsequentes, decorre da aproximação comercial do Brasil com a China.

Quando se analisa a relação econômica entre dois traders geralmente o primeiro elemento utilizado é a balança comercial. No período que envolve dezessete anos [2003-2019] a balança comercial de Alagoas com a China se mostra deficitária na maioria dos anos, havendo superávit apenas em 2004 e 2015 (Gráfico 1). Experiência contrária do âmbito nacional.

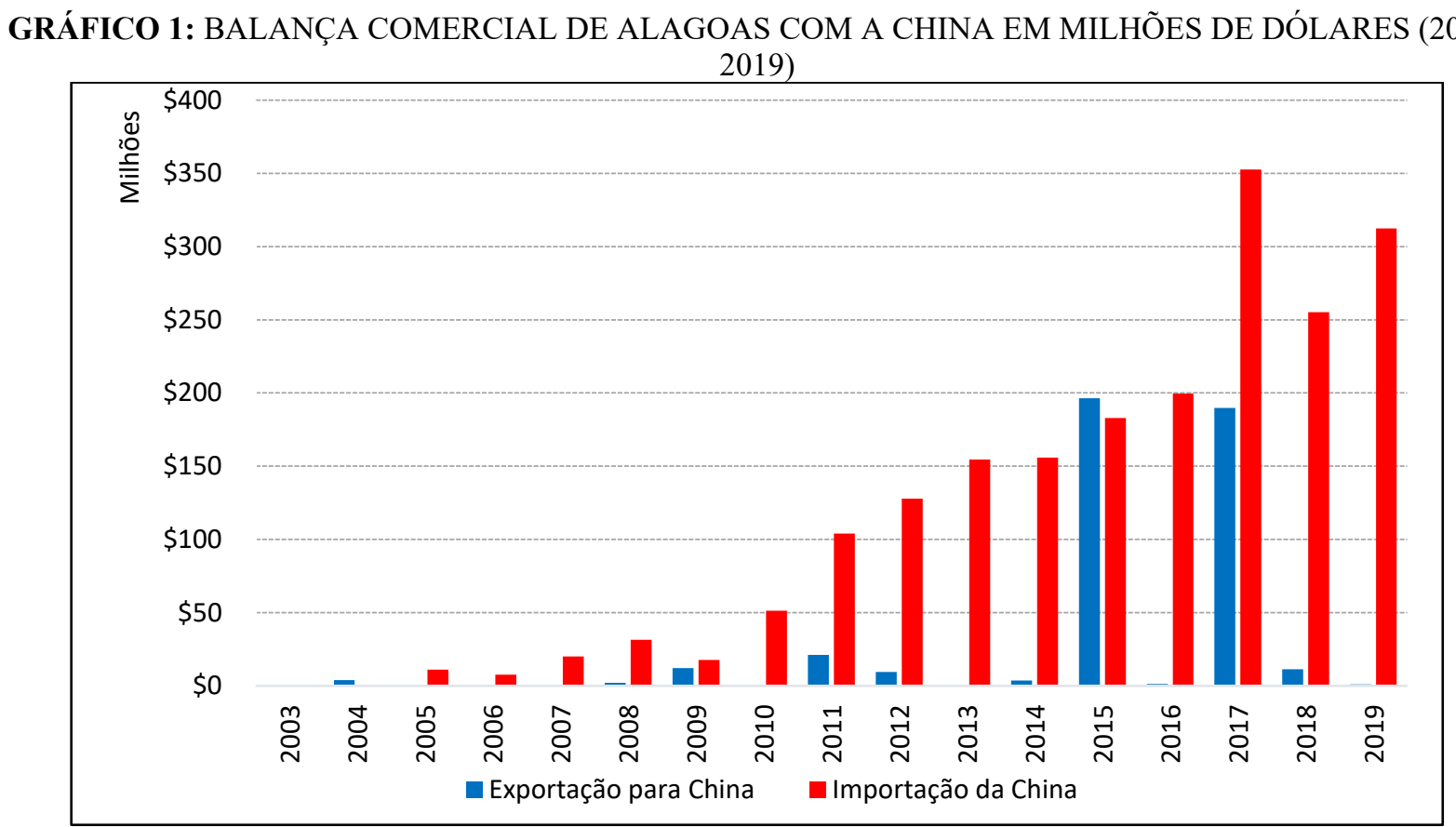

Fonte: Ministério da Economia (2020).

Verifica-se que o ritmo de crescimento das importações não foi acompanhado pelas exportações, que apesar de dois picos, em 2015 e 2017, não alcançou os três dígitos nos demais anos do período em análise.

As importações, por sua vez, cresceram constantemente de 2010 a 2017. Em 2011, o valor total das importações de Alagoas com origem na China dobrou em relação a 2010, atingindo a casa dos três dígitos [104 milhões de dólares], e em 2017, quando o valor das importações saltou para 352 milhões de dólares, ante 199 milhões de dólares em 2016. 
Analisando as transações comerciais Alagoas-China que envolvem duas décadas, podemos distingui-las em dois períodos. A primeira década [2003-2010] com valores de exportação e importação bastante tímidos, quando o fluxo comercial estava em vias de consolidação. E a segunda década [2011-2019] com o fluxo comercial consolidado e atingindo a marca dos três dígitos pela via importadora e pela via exportadora em 2015 e 2017. Para entender melhor os dois momentos, o total das importações entre 2003 e 2010 somam 139 milhões de dólares, valor inferior ao total importado apenas no ano de 2013 que foi 154 milhões de dólares. Já o total das exportações entre 2003 e 2010 somam 18 milhões de dólares, valor inferior ao total exportado no ano de 2011 com 21 milhões de dólares ${ }^{1}$.

\section{Exportações alagoanas com destino à China}

No campo das exportações Alagoas se beneficia pouco do comércio com a China, somente a partir de 2004 é registrado a exportação de produtos alagoanos diretamente à China, sucedido por alguns anos de exportações escassas ou praticamente escassas [2005, 2006, 2007, 2010, 2013], ver Tabela 1.

Isto porque os principais produtos industrializados de Alagoas [açúcar e leite] não ocupam posição de destaque na pauta de exportação com destino à China. O leite e seus derivados, produzidos pela pecuária leiteira com presença marcante no semiárido do estado, são voltados ao mercado interno. Já o açúcar, principal item de exportação do estado com $89 \%$ de participação no total exportado em 2019, destina-se tradicionalmente aos países europeus, Estados Unidos e Canadá ${ }^{2}$

TABELA 1: PARTICIPAÇÃO DA CHINA NAS EXPORTAÇÕES DE ALAGOAS EM DÓLARES (2004-2019)

\begin{tabular}{lrrc}
\hline Ano & $\begin{array}{c}\text { Exportação } \\
\text { Total }\end{array}$ & $\begin{array}{c}\text { Exportação p/ } \\
\text { China }\end{array}$ & $\begin{array}{c}\text { Participação } \\
\text { China (\%) }\end{array}$ \\
\hline 2019 & 319.088 .835 & 870.032 & $0,3 \%$ \\
2018 & 502.094 .696 & 11.230 .651 & $2,2 \%$ \\
2017 & 665.014 .889 & 189.828 .551 & $28,5 \%$ \\
2016 & 420.859 .938 & 1.192 .202 & $0,3 \%$ \\
2015 & 672.248 .170 & 196.398 .026 & $29,2 \%$ \\
2014 & 629.144 .686 & 3.752 .581 & $0,6 \%$ \\
2013 & 741.919 .441 & 196.593 & $0,0 \%$ \\
2012 & 1.014 .101 .751 & 9.455 .351 & $0,9 \%$ \\
2011 & 1.371 .188 .500 & 21.039 .314 & $1,5 \%$ \\
2010 & 970.594 .666 & - & - \\
2009 & 823.950 .944 & 12.220 .157 & $1,5 \%$
\end{tabular}

\footnotetext{
${ }^{1}$ Nos anos de 2003, 2006, 2007 e 2010 não houve registro de exportação de Alagoas com destino à China.

${ }^{2}$ Em 2018 e 2019 a Argélia passou a figurar entre os cinco principais destinos de exportação. 


\begin{tabular}{lrrc}
2008 & 876.554 .213 & 2.016 .128 & $0,2 \%$ \\
2007 & 663.661 .517 & - & - \\
2006 & 692.542 .362 & - & - \\
2005 & 583.779 .056 & 7.875 & $0,0 \%$ \\
2004 & 457.657 .629 & 3.977 .027 & $0,9 \%$ \\
\hline
\end{tabular}

Fonte: Ministério de Economia (2020).

Distorcendo a tendência majoritária ao longo dos anos, em 2015 e 2017, a participação chinesa nas exportações de Alagoas alcança 29,2\% e 28,5\%, maiores taxas do período. Diferente da pauta de exportação com destino aos países europeus, Estados Unidos e Canadá, quase restrita a produtos primários [açúcar], nas exportações com destino à China, nestes dois anos, predominaram máquinas e equipamentos. Em 2015 a ordem foi a seguinte: máquinas e equipamentos [86,9\%] e produtos alimentícios [13,0\%]. Já em 2017 foi: máquinas e equipamentos [90,4\%] e produtos alimentícios [9,1\%] (MINISTÉRIO DA ECONOMIA, 2020).

Mesmo considerando os dois anos mais favoráveis das exportações, seu valor total comparado às exportações dos estados do Centro-Oeste para a China é baixo, já que a demanda chinesa no Brasil é principalmente por commodities agrícolas. No entanto, no contexto regional as exportações alagoanas são consideráveis, haja vista que, as exportações de Pernambuco, segunda maior economia da região, destinadas à China, totalizaram 126 milhões de dólares em 2015 e 14,5 milhões de dólares em 2017 (MINISTÉRIO DA ECONOMIA, 2020).

A combinação de fatores internos e externos, aliados à presença chinesa na economia de Alagoas, tem repercutido em mudanças na estrutura econômica do estado desde a última década. Desde 2012 houve redução do setor canavieiro, desestimulado pela queda dos preços das commodities e perda da competitividade do álcool no mercado interno, levando o setor à crise e ao fechamento de sete usinas. A perda de participação do setor canavieiro na economia estadual, acarretou na ampliação da pecuária leiteira, com seus produtos presentes no mercado interno e destinados para indústrias em Pernambuco e Sergipe (CARVALHO, 2019).

A redução da área destinada ao cultivo da cana, na Zona da Mata alagoana, tem sido ocupada pela policultura com o cultivo de frutas, feijão, algodão e notadamente milho e soja ${ }^{3}$. Estas duas culturas têm se destacado em termos de cultivo e produtividade, estimuladas pelo preço da saca. A soja é o principal produto brasileiro exportado para a China. Em Alagoas, a soja comandou a pauta de exportação destinada à China nos anos de 2014, 2016 e 2018. O cultivo da soja no estado apoiado pela Embrapa, Emater e Secretaria de Agricultura está em fase experimental, mas, com perspectivas

\footnotetext{
${ }^{3}$ Segundo os dados da Produção Agrícola Municipal do IBGE (2019) a área plantada de cana-de-açúcar em Alagoas caiu de 433 mil hectares em 2012 para 304 mil hectares em 2019.
} 
promissoras, e tem atraído produtores das regiões Sul e Centro-Oeste do país (CARVALHO, 2019; LIMA, 2019).

As exportações alagoanas para a China além de não terem acompanhado o ritmo de crescimento das importações, não aumentou o portfólio de seus produtos. Nos últimos quatro anos em análise, os maiores valores dos produtos exportados se limitaram a soja, cobre, açúcar, centrifugadores e filamentos sintéticos. Apesar do curto período de tempo da Tabela 2, é possível observar a constante variação entre os produtos que comandam a pauta de exportação e os tipos de produtos [alimentícios, minerais, químicos e máquinas]. Os únicos produtos a ultrapassarem a casa do milhão de dólares foram a soja, em 2018, centrifugadores e açúcar, em 2017.

TABELA 2: EXPORTAÇÕES DE ALAGOAS PARA A CHINA POR PRODUTOS (2016-2019)

\begin{tabular}{|c|c|c|c|}
\hline Ano & Produtos & $\begin{array}{l}\text { Valor FOB } \\
\text { (US\$) }\end{array}$ & $\%$ US\$ \\
\hline \multirow{7}{*}{ 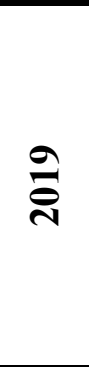 } & Fios de filamentos sintéticos & 396.390 & $\overline{45,6}$ \\
\hline & Cobre e resíduos & 374.280 & 43,0 \\
\hline & Polímeros de cloreto de vinilo & 37.958 & 4,4 \\
\hline & Roupas de malha & 21.566 & 2,4 \\
\hline & Carnes frescas ou congeladas & 2.291 & 0,3 \\
\hline & Outros & 37.547 & 4,3 \\
\hline & Total & 870.032 & 100,0 \\
\hline \multirow{4}{*}{ 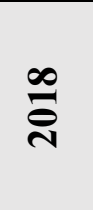 } & Soja & 10.500 .000 & 93,5 \\
\hline & Cobre e resíduos & 435.294 & 3,9 \\
\hline & Fios de filamentos sintéticos & 295.357 & 2,6 \\
\hline & Total & 11.230 .651 & 100,0 \\
\hline \multirow{6}{*}{ 곡 } & Centrifugadores & 171.657 .240 & 90,4 \\
\hline & Açúcar & 17.272 .793 & 9,1 \\
\hline & Cobre e resíduos & 663.753 & 0,4 \\
\hline & Alumínio e resíduos & 206.505 & 0,1 \\
\hline & $\begin{array}{l}\text { Mármores, travertinos, granitos belgas } \\
\text { e outras pedras de construção }\end{array}$ & 28.260 & 0,01 \\
\hline & Total & 189.828 .551 & 100,0 \\
\hline \multirow{4}{*}{ 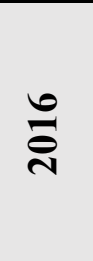 } & Soja & 806.860 & 67,7 \\
\hline & Cobre e resíduos & 366.836 & 30,8 \\
\hline & $\begin{array}{l}\text { Granito, pórfiro, basalto, arenito e } \\
\text { outras pedras de construção }\end{array}$ & 18.506 & 1,5 \\
\hline & Total & 1.192.202 & 100,0 \\
\hline
\end{tabular}

Fonte: Ministério da Economia (2020).

O fato de o açúcar ter constado na segunda colocação de produtos exportados para China em 2017 foi momentâneo. O principal produto de exportação de Alagoas aproveitou o momento de boom 
das exportações para a China, principal mercado do açúcar brasileiro até 2017, quando o país elevou a tarifa de volumes extra-cota em meados do mesmo ano. A China estabelece uma cota de importação anual de 1,9 milhão de toneladas para o açúcar brasileiro. A elevação da tarifa para produtos extracota reduziu as exportações brasileiras nos anos seguintes, repercutindo em Alagoas, que possui usinas menos competitivas perante as usinas do Sudeste (EXAME, 2020).

A baixa quantidade de produtos exportados pelo estado destinados à China também é acompanhada pela quantidade de municípios que participam da exportação (Mapa 1). Selecionando o ano de 2017, ano mais recente que registrou maior valor de exportação, constata-se que apenas três municípios participaram da exportação: Maceió com 180,2 milhões de dólares, Coruripe e São Miguel dos Campos, respectivamente com 3,7 e 2,2 milhões de dólares.

A capital Maceió, naturalmente ocupa a primeira colocação por ser o centro econômicoadministrativo e abrigar o único porto de exportação do estado. Os municípios de Coruripe e São Miguel dos Campos possuem as maiores usinas do estado, em termos de produção de açúcar. A Usina Coruripe, que leva o nome do município, e a Usina Caeté em São Miguel dos Campos foram responsáveis por um terço da produção de açúcar de Alagoas em 2018 e estão situadas no sul do estado, região que concentra maiores áreas de produtividade de cana-de-açúcar (ALAGOAS, 2018).

MAPA 1: EXPORTAÇÕES ALAGOANAS COM DESTINO À CHINA POR MUNICÍPIO EM 2017 (US\$)

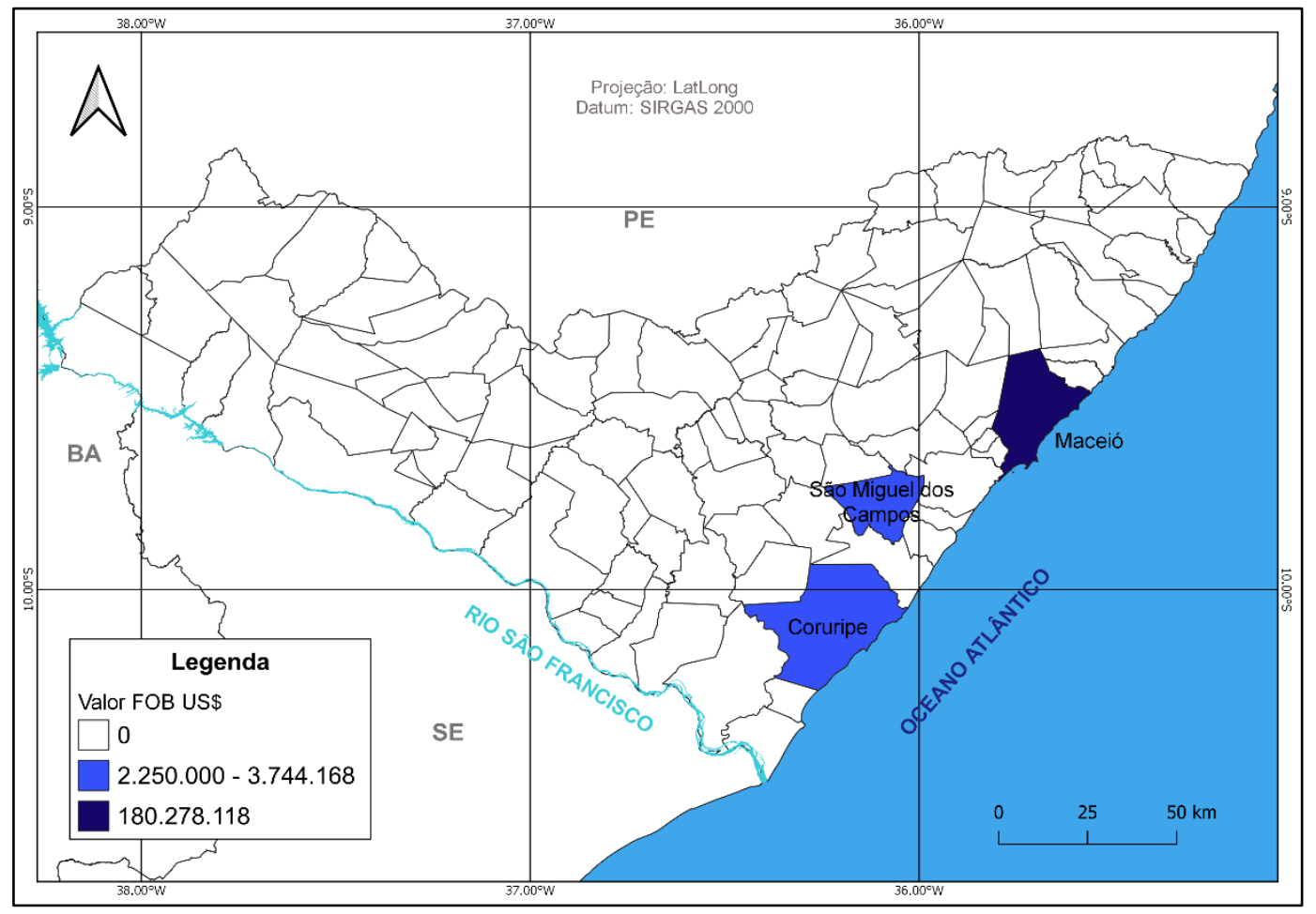

Fonte: Ministério da Economia, (2020). Elaborado pelos autores. 
A pouca diversificação da indústria e agricultura de exportação do estado, justificam o baixo valor das exportações para a China. Considerando os dados de 2018, os setores da construção, alimentos e químicos, representam $62 \%$ do valor da transformação industrial e o estado é apenas o décimo sétimo colocado nas exportações industriais no país. Ou seja, as atividades industriais que predominam em Alagoas são voltadas ao mercado interno. No setor agrícola, apesar da recente diversificação com o recuo das áreas de cana, o cultivo da soja está em fase experimental. Diferente da cana, uma cultura consolidada e de presença secular em Alagoas, mantendo-se como o único produto agrícola exportado em larga escala (CNI, 2018).

\section{Importações alagoanas com origem na China}

As importações alagoanas com origem na China apresentam uma dinâmica diferente diante das exportações. Desde 2010 as importações crescem constantemente em termos de valor e contém um portfólio mais variado. Parte desse aumento se deve às políticas sociais e de estímulo ao mercado interno pelo governo federal entre 2003 e 2014, contribuindo no crescimento do PIB e da renda no estado de Alagoas.

Segundo os dados do Ministério da Economia (2020) o registro de importações realizadas por Alagoas diretamente da China ocorre a partir de 2003. Conforme a Tabela 3, em apenas dois anos, a China alcançou $11,5 \%$ de participação nas importações alagoanas. Após ter dobrado o valor das importações entre 2010-2011, a China se torna definitivamente o maior parceiro comercial de Alagoas pela via importadora, em 2012, desbancando os Estados Unidos. Em 2017, a China respondeu por mais da metade do valor total das importações alagoanas, sendo o ano com maior participação do país no período analisado.

O crescimento das importações chinesas coincide com o período de rápido crescimento da economia alagoana, após a recuperação da crise fiscal dos anos 1990 e sob o reflexo do bom desempenho da economia nacional. As políticas de transferência de renda e de valorização do salário mínimo aumentaram o poder de compra da população e o consumo interno se tornou um fator importante na economia estadual (CARVALHO, 2019). 
TABELA 3: PARTICIPAÇÃO DA CHINA NAS IMPORTAÇÕES DE ALAGOAS 2003-2019 (US\$)

\begin{tabular}{llrc}
\hline Ano & $\begin{array}{c}\text { Importação } \\
\text { Total }\end{array}$ & $\begin{array}{c}\text { Importação- } \\
\text { China }\end{array}$ & $\begin{array}{c}\text { Participação no } \\
\text { total das } \\
\text { importações (\%) }\end{array}$ \\
\hline 2019 & 665.943 .197 & 312.392 .741 & 46,9 \\
2018 & 589.833 .204 & 255.156 .738 & 43,3 \\
2017 & 644.426 .485 & 352.540 .020 & 54,7 \\
2016 & 612.011 .259 & 199.480 .140 & 32,6 \\
2015 & 602.546 .344 & 182.970 .815 & 30,4 \\
2014 & 563.906 .991 & 156.029 .690 & 27,7 \\
2013 & 496.367 .485 & 154.477 .036 & 31,1 \\
2012 & 421.528 .662 & 127.841 .782 & 30,3 \\
2011 & 451.381 .162 & 104.047 .768 & 23,1 \\
2010 & 248.619 .734 & 51.338 .258 & 20,6 \\
2009 & 113.479 .479 & 17.782 .978 & 15,7 \\
2008 & 219.767 .078 & 31.524 .962 & 14,3 \\
2007 & 239.008 .214 & 20.147 .930 & 8,4 \\
2006 & 115.843 .739 & 7.718 .840 & 6,7 \\
2005 & 97.402 .861 & 11.185 .647 & 11,5 \\
2004 & 68.142 .489 & 82.677 & 0,1 \\
2003 & 48.624 .508 & 6.065 & $<0,1$ \\
\hline
\end{tabular}

Fonte: Ministério da Economia, (2020).

Em linhas gerais, a variação do PIB de Alagoas acompanhou o ritmo da economia regional, ver Gráfico 2. Entre 2004 e 2014, anos de maior crescimento, o PIB de Alagoas registrou média de crescimento ligeiramente maior que a média do PIB do Nordeste, 4,4\% e 4,3\% respectivamente. Interessante notar que os anos de maior crescimento do PIB de Alagoas, de 2010 a 2012, registrando crescimento acumulado de $18,5 \%$, corresponde ao momento que as importações oriundas da China dobraram e o país se tornou o maior parceiro comercial de Alagoas; comparar a tabela anterior.

Diante da crise econômica nacional, a economia do estado registra um tombo em 2015 e 2016, com o PIB caindo para $-3,0 \%$ e $-1,3 \%$ respectivamente. Revelando a dependência da economia estadual dos investimentos federais e do mercado interno, dependente em grande medida dos programas de transferência de renda. Em 2017, a retomada econômica de Alagoas registra crescimento de 3,3\% do PIB, superior ao crescimento de 1,3\% do PIB regional. Neste mesmo ano de recuperação econômica, as importações alagoanas com origem na China quase dobraram de valor em relação a 2016. 
GRÁFICO 2: ALAGOAS E NORDESTE: VARIAÇÃO DO PIB ENTRE 2004 E 2018 (\%)

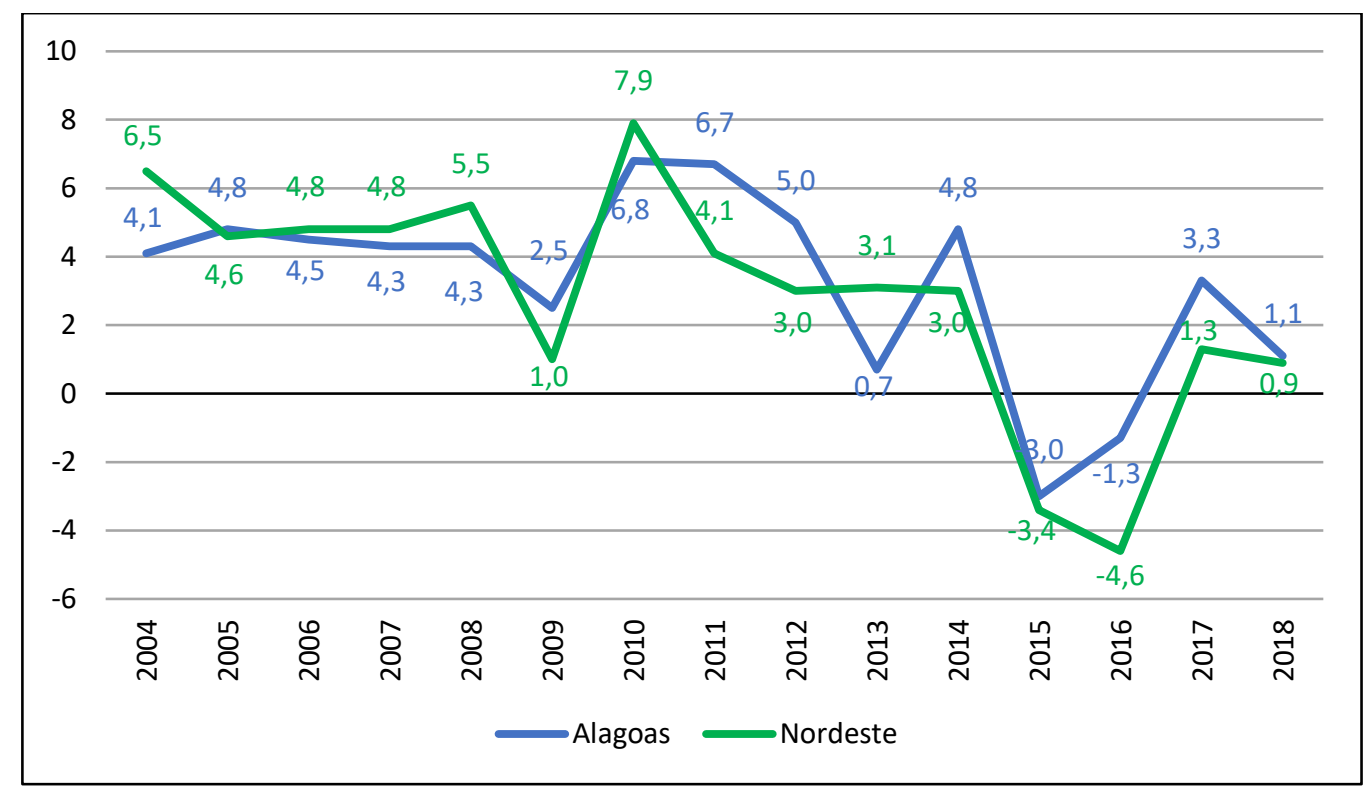

Fonte: IBGE, vários anos; SEPLAG-AL, vários anos. Elaborado pelos autores.

Apesar do período de crescimento econômico ter refletido no aumento de importações, não se pode ignorar os efeitos positivos na economia alagoana. A conjuntura nacional de crescimento, contribuindo em novos investimentos e formalização da mão de obra, aumentou o contingente de trabalhadores formalizados e impulsionou grandes obras de infraestrutura no estado. A exemplo da construção de adutoras nos municípios do semiárido, duplicação de rodovias e ampliação do Porto de Maceió, expandindo suas atividades para o segmento offshore em 2012 (APMC, 2018).

Entre 2000 e 2014 o número de assalariados subiu de 272 mil para 514 mil, principalmente pela oferta de empregos em segmentos que contratam mão de obra com pouca qualificação e de menor remuneração [comércio, serviços e construção civil]. Foi justamente o número de trabalhadores da faixa salarial entre um e dois salários mínimos que mais cresceu no período, passando de 58\% para $72 \%$ do total de contratados em Alagoas (CARVALHO, 2019).

O aumento da renda e do poder de compra da população alagoana, repercute também no mercado interno, principalmente nos segmentos ligados a baixa renda. Os dados da Pesquisa Mensal do Comércio do IBGE indicam o boom de consumo no setor varejista entre 2005 e 2014 com o crescimento nas vendas acima dos dois dígitos, excetuando o ano de 2012, ver Tabela 4.

O período de maior crescimento das vendas no varejo coincide com os anos de maior crescimento do PIB, comparar o gráfico anterior. Atrelado ao aumento do consumo da população de baixa renda, Carvalho (2019) destaca o crescimento das micro e pequenas empresas, espalhadas pela periferia das cidades do litoral e interior; em 2018, das 168 mil empresas legalizadas em Alagoas, 146 mil são do setor de comércio e serviços. 
TABELA 4: VARIAÇÃO DA RECEITA DAS VENDAS NO COMÉRCIO VAREJISTA EM ALAGOAS ACUMULADO NOS 12 MESES (\%)

\begin{tabular}{cccccccc}
\hline $\mathbf{2 0 0 4}$ & $\mathbf{2 0 0 5}$ & $\mathbf{2 0 0 6}$ & $\mathbf{2 0 0 7}$ & $\mathbf{2 0 0 8}$ & $\mathbf{2 0 0 9}$ & $\mathbf{2 0 1 0}$ & $\mathbf{2 0 1 1}$ \\
6,0 & 18,7 & 22,2 & 16,9 & 21,8 & 13,4 & 13,9 & 16,5 \\
$\mathbf{2 0 1 2}$ & $\mathbf{2 0 1 3}$ & $\mathbf{2 0 1 4}$ & $\mathbf{2 0 1 5}$ & $\mathbf{2 0 1 6}$ & $\mathbf{2 0 1 7}$ & $\mathbf{2 0 1 8}$ & $\mathbf{2 0 1 9}$ \\
5,6 & 13,0 & 15,6 & 8,3 & $-1,4$ & 5,2 & 8,2 & 2,6 \\
\hline
\end{tabular}

Fonte: Pesquisa Mensal do Comércio - IBGE, vários anos.

O forte crescimento do setor, paralelo a baixa diversificação industrial e a crise na atividade canavieira, amplia sua participação no valor adicionado do PIB estadual. O setor de serviços que respondia por $68,7 \%$ do valor adicionado em 2010, aumenta a participação para 73,3\% em 2015. Já o setor industrial sofre retração de $-4,1 \%$ e a agropecuária de $-0,4 \%$ no mesmo período (SEPLAG, 2016).

Outro fator de destaque, próprio à dinâmica interna de Alagoas é a urbanização. Conforme destacado anteriormente, a urbanização é um fato relativamente recente no estado, se comparado à experiência do Sudeste. Mesmo no século XXI, a população urbana teve aumento expressivo, saltando de 68\%, em 2000, para 74\%, em 2018. Esse processo também repercutiu na ampliação de atividades tipicamente urbanas, como comércio e serviços (CARVALHO, 2019).

Na Tabelas 5 e 6, vemos um portfólio maior de produtos chineses importados por Alagoas em comparação às exportações. Nos anos de 2005 e 2010, predominam produtos de média e baixa intensidade tecnológica. Em 2010, aumenta a concentração da pauta de importação com os têxteis respondendo por mais da metade do valor importado; quando em 2005 obteve apenas 8,5\% de participação.

Vale destacar que os produtos têxteis estão diretamente ligados ao consumo das famílias, a forte alta na participação em 2010 corresponde ao período do boom de consumo em Alagoas, estimulado também pela valorização cambial no âmbito macroeconômico. A taxa média do câmbio, em 2010, atingiu o menor valor da década R\$ 1,60/dólar (IPEA, 2021).

Nos dois anos em questão, observa-se inclusive que alguns produtos importados deixaram de ter destaque em 2010, a exemplo de equipamentos elétricos, dando lugar a outras manufaturas; e produtos informáticos, eletrônicos e ópticos o mais importado em 2005, ocupando a oitava colocação com participação de apenas 2,5\% no total importado em 2010. 
TABELA 5: PRINCIPAIS PRODUTOS IMPORTADOS DA CHINA POR ALAGOAS 2005 E 2010 (\% US\$)

\begin{tabular}{lrlr}
\hline \multicolumn{1}{c}{$\mathbf{2 0 0 5}$} & $\mathbf{\%}$ & \multicolumn{1}{c}{$\mathbf{2 0 1 0}$} & $\mathbf{\%}$ \\
\hline Produtos informáticos, eletrônicos e & 42,4 & Têxteis & 65,8 \\
ópticos & 22,3 & Vestuário & 5,5 \\
Vestuário & 9,2 & Outras manufaturas & 4,0 \\
Equipamentos elétricos & 8,5 & Couro e produtos afins & 3,9 \\
Têxteis & 4,8 & Metais básicos & 3,0 \\
Outras manufaturas & 4,4 & Produtos químicos & 2,9 \\
Máquinas e equipamentos & 2,5 & Máquinas e equipamentos & 2,8 \\
Produtos de borracha e plásticos & 2,3 & Produtos informáticos, eletrônicos & 2,5 \\
Produtos químicos & 2,3 & Produtos minerais não metálicos & 2,2 \\
Couro e produtos afins & 0,6 & Produtos alimentícios & 1,4 \\
Móveis & $\mathbf{9 9 , 3}$ & TOTAL & $\mathbf{9 4 , 0}$ \\
TOTAL & $\mathbf{0 , 7}$ & Outros produtos & $\mathbf{6 , 0}$ \\
Outros produtos & &
\end{tabular}

Fonte: Ministério da Economia, (2020).

Na pauta de importação, vestuário registra grande destaque nos anos selecionados; em 2015 e 2019, foi o produto chinês mais importado por Alagoas (Tabelas 5 e 6). Em 2015, a presença de produtos com maior intensidade tecnológica aumentou, equipamentos de transporte, que não aparece entre os principais importados em anos anteriores selecionados, e equipamentos elétricos respondem por $26 \%$ do total importado.

TABELA 6: PRINCIPAIS PRODUTOS IMPORTADOS DA CHINA POR ALAGOAS 2015 E 2019 (\% US\$)

\begin{tabular}{lrlr}
\hline \multicolumn{1}{c}{$\mathbf{2 0 1 5}$} & $\mathbf{\%}$ & \multicolumn{1}{c}{$\mathbf{2 0 1 9}$} & $\mathbf{\%}$ \\
\hline Vestuário & 24,4 & Vestuário & 30,0 \\
Equipamentos de transporte & 15,9 & Equipamentos elétricos & 10,3 \\
Equipamentos elétricos & 10,1 & Couro e produtos afins & 8,2 \\
Couro e produtos afins & 10,1 & Produtos informáticos, & 7,6 \\
Produtos químicos & 7,3 & Produtos químicos & 7,6 \\
Têxteis & 7,1 & Produção vegetal, animal e caça & 5,4 \\
Produtos minerais não metálicos & 3,9 & Produtos metálicos fabricados & 5,2 \\
Outras manufaturas & 3,4 & Máquinas e equipamentos & 4,8 \\
Produtos informáticos, eletrônicos e & 3,3 & Produtos de borracha e plásticos & 4,6 \\
Ópticos & 3,0 & Produtos minerais não metálicos & 3,8 \\
Produtos de borracha e plásticos & $\mathbf{8 8 , 5}$ & TOTAL & $\mathbf{8 7 , 5}$ \\
TOTAL & $\mathbf{1 1 , 5}$ & Outros produtos & $\mathbf{1 2 , 5}$ \\
Outros produtos & &
\end{tabular}

Fonte: Ministério da Economia, (2020). 
Destaque também o couro e produtos químicos que aumentaram a participação de 2,3\% cada, em 2005, para 8,2\% e 7,6\% respectivamente, em 2019. Já na queda de participação, destaque para os produtos informáticos, eletrônicos e ópticos, mais importado em 2005, com 42,4\% de participação, nos anos selecionados posteriores a participação ficou abaixo dos dois dígitos, 2,5\% em 2010, 3,3\% em 2015, e 7,6\% em 2019.

Em geral, observando os anos selecionados, houve desconcentração no portfólio das importações com os produtos do topo da tabela registrando menor participação e os produtos da base da tabela aumentando sensivelmente a participação. No decorrer dos anos, a desconcentração entre os importados é acompanhada por uma ligeira diversificação ao comparar os percentuais totais dos principais produtos importados aos outros produtos.

Categorizando os dez produtos chineses mais importados por Alagoas em 2019 por intensidade tecnológica, predominam produtos na categoria média-baixa somando $43,4 \%$ de participação, com destaque ao item vestuário (Figura 1).

O predomínio da categoria média-baixa é condizente às características socioeconômicas de Alagoas, formado por um mercado consumidor de baixo poder aquisitivo, pouca presença industrial e um setor de comércio e serviços onde a dinâmica é ditada pelas micro e pequenas empresas.

\section{FIGURA 1: DEZ MAIORES IMPORTÁVEIS CHINESES POR ALAGOAS EM 2019 POR INTENSIDADE} TECNOLÓGICA

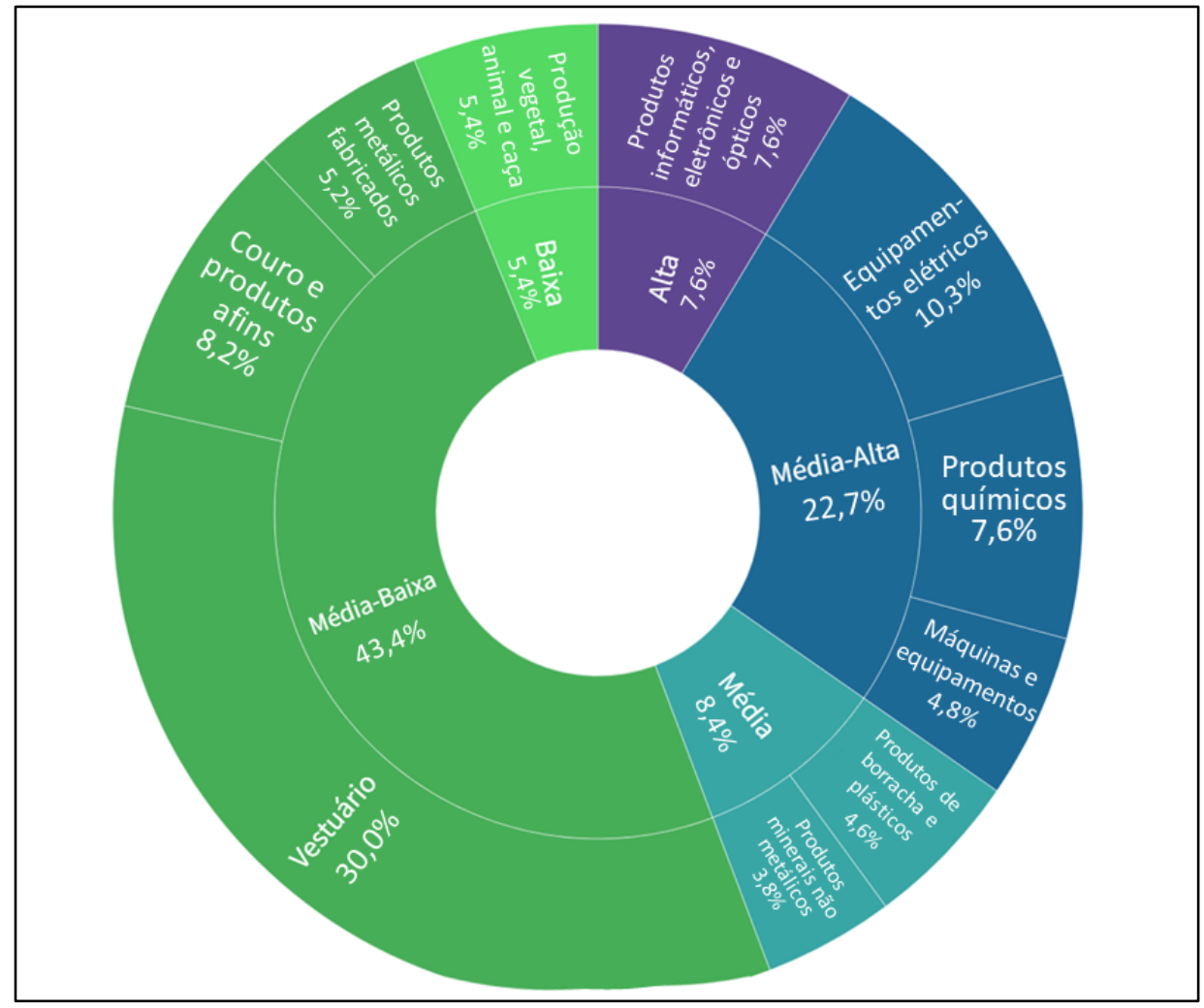

Fonte: OCDE, (2016); Ministério da Economia, (2020). Elaborado pelos autores. 
Em conjunto, as categorias média-baixa, média e média-alta somam $74,5 \%$ de participação entre os principais importáveis em 2019. Equipamentos elétricos tem a maior participação na categoria média-alta e produtos de borracha e plásticos praticamente dividem a participação com os produtos minerais não metálicos na categoria média. Se compararmos os anos anteriores (Tabelas 5 e 6), as categorias média-baixa, média e média-alta continuam majoritárias entre os principais importáveis, inclusive no ano 2005, quando os produtos informáticos, eletrônicos e ópticos, de alta intensidade tecnológica, registraram 42,4\% de participação.

No mesmo ano, analisando a importação de produtos chineses por município, encontramos maior participação de municípios em relação à exportação. Segundo os dados do Ministério da Economia (2020) dez municípios participaram da atividade de importação, concentrados na região litorânea do estado, conforme o Mapa 2.

\section{MAPA 2: IMPORTAÇÕES ALAGOANAS COM ORIGEM NA CHINA POR MUNICÍPIO EM 2019 (US\$)}

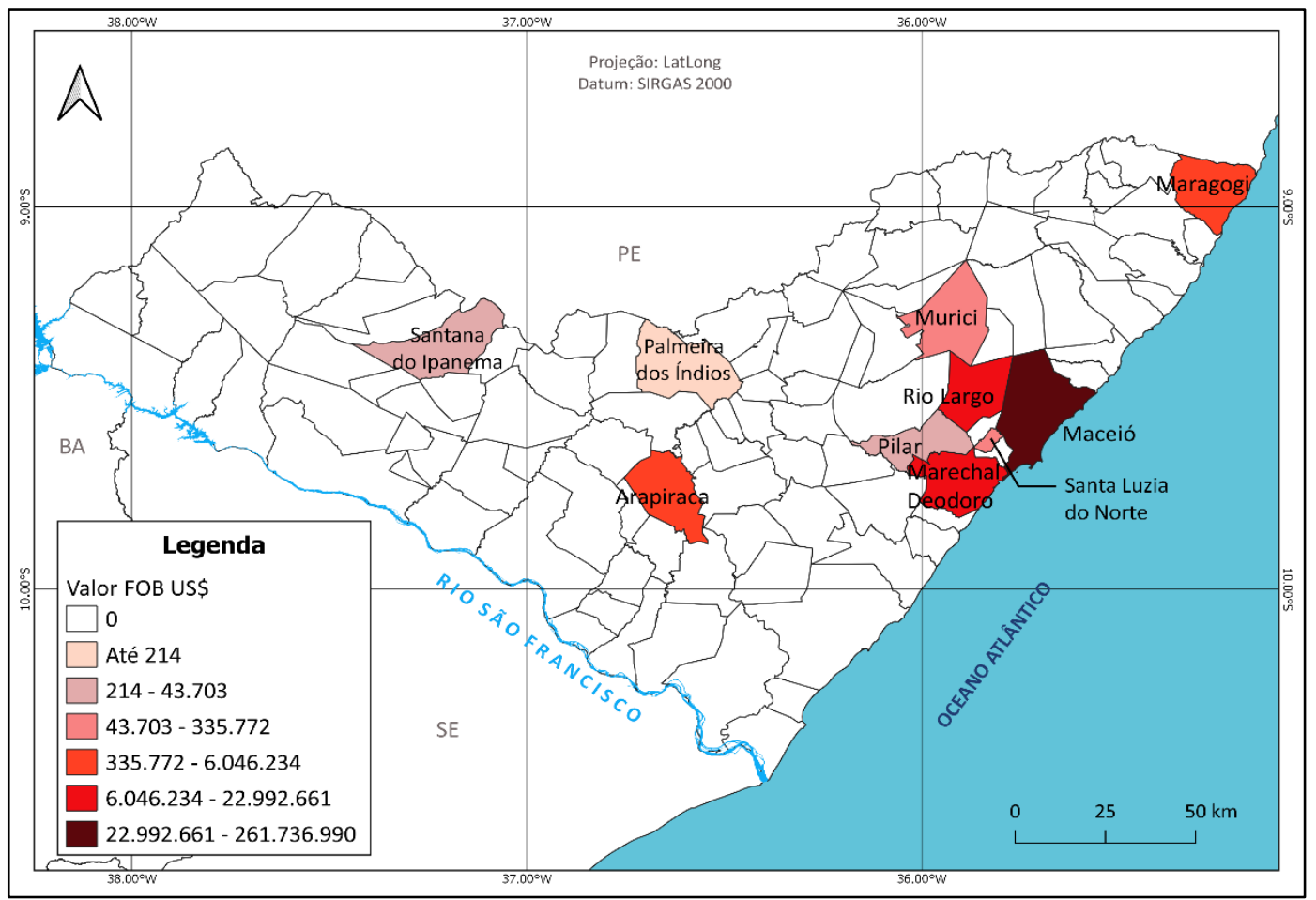

Fonte: Ministério da Economia, (2020). Elaborado pelos autores.

Maceió lidera as importações em 2019, totalizando quase 262 milhões de dólares, seguido por Marechal Deodoro com US\$ 22,9 milhões, Rio Largo com US\$ 20,2 milhões e Maragogi com US\$ 6 milhões. No interior do estado, o principal município importador foi Arapiraca, porém, com valor muito abaixo dos municípios da região litorânea, apenas 726 mil dólares. A posição de destaque desses municípios nas importações coincide com a expressividade econômica que possuem na 
economia de Alagoas. Os municípios de Maceió, Marechal Deodoro, Rio Largo e Arapiraca estão entre os cinco maiores PIB do estado. Além de Maceió, Arapiraca e Rio Largo, possuírem os maiores contingentes de microempreendedores individuais (ALAGOAS, 2018; IBGE, 2018).

Entre os principais produtos importados por município, Maceió, principal centro consumidor do estado, se destaca pela importação de vestuário, eletrônicos, máquinas e equipamentos elétricos, correspondendo a 40\% do total importado pelo município em 2019.

Já o município de Marechal Deodoro, importante polo industrial do estado, o destaque das importações foram alumínio, eletrônicos, máquinas e equipamentos elétricos e mecânicos, correspondendo a 72\% das importações. Segundo o Zoneamento Industrial de Alagoas da Fiea (2014) na atividade industrial do município destacam-se a fabricação de embalagens e materiais plásticos e manutenção de máquinas e equipamentos industriais. Após a instalação da petroquímica Braskem no município de Maceió nos anos 1980, formou-se em Marechal Deodoro uma importante cadeia de indústrias químicas e de plástico. Com a inauguração de nova fábrica da Braskem no município em 2012, Alagoas se tornou o maior produtor de PVC das Américas.

Em Rio Largo, a pauta de importação é mais concentrada, com os químicos orgânicos representando 57\% do total das importações em 2019. Apesar de o município figurar entre os maiores PIB's do estado, não possui atividade industrial expressiva, mantendo a forte presença do setor canavieiro em sua economia. Em Maragogi, principal economia do litoral norte do estado com forte presença da atividade turística na economia, artigos de couro, bolsas e acessórios responderam por 91\% das importações.

O município de Arapiraca, por sua vez, é a principal economia do agreste e sertão alagoano, e segunda maior economia do estado. De forte tradição comercial, constituiu importante polo alimentício e de distribuição comercial no estado. Peixes, crustáceos e frutas foram os principais produtos chineses importados pelo município, respondendo por $85 \%$ do total importado.

Nos últimos anos, o setor de distribuição comercial se tornou o principal segmento econômico de Alagoas, com a presença dessas empresas locais no mercado dos estados vizinhos de Sergipe e Pernambuco, e suas receitas superando as do setor canavieiro. Já no setor alimentício, Arapiraca é sede do grupo Coringa, segunda maior empresa de alimentos em faturamento em Alagoas, de capital local e voltada ao mercado de baixa renda. No campo, baseada na pequena produção, Arapiraca aprimorou sua policultura através do projeto Cinturão Verde, envolvendo 16 povoados do município na produção de verduras e hortaliças que atualmente são exportadas para diversas cidades alagoanas (CARVALHO, 2019; MENDES, 2020). 
Os demais municípios, com valores abaixo de 335 mil dólares em importação, apresentam uma pauta de importação bastante restrita, com apenas dois ou três produtos chineses. Em geral, destacam-se equipamentos mecânicos e utensílios domésticos.

Vale destacar que o ranking das maiores importações com origem chinesa em Alagoas não necessariamente corresponde a posição do município na economia do estado. O valor agregado dos produtos importados pelos municípios, interferem diretamente neste ranking de importações. É o caso de Arapiraca, segunda maior economia de Alagoas, aparece como o quinto maior importador em produtos chineses, isto porque, seus importados são de baixo valor agregado. À medida que Maragogi, décima maior economia do estado, aparece à frente de Arapiraca por importar produtos chineses de maior valor agregado.

\section{Recentes investimentos chineses em Alagoas}

Antes de pontuar os investimentos da China em Alagoas, é necessário ressaltar que tais realizações estão sob a influência das relações comerciais Brasil-China, fortalecida nas últimas décadas. A ascensão da China como maior parceiro comercial do Brasil, repercute em Alagoas através do crescimento das importações, e exportações em anos específicos, investimentos no setor industrial e em empresas alagoanas, bem como, na busca ativa por parte do governo estadual por novos investimentos chineses. Esse movimento ficou mais evidente nos últimos anos, diante do baixo ritmo de crescimento das economias europeias e norte-americana, tradicionais fontes de financiamento em Alagoas.

A fábrica de condutores elétricos e de fibra óptica ZTT, localizada no município de Marechal Deodoro, é o principal investimento chinês já realizado no estado (Figura 2). Inaugurada em 2015 com investimento de R \$ 35 milhões e perspectiva de ampliação da planta fabril, é a primeira fábrica do gênero no Nordeste. Sediada em Xangai, na China, está entre os maiores fabricantes de condutores elétricos e fibra óptica do mundo e seu investimento em Alagoas resulta de joint venture com a empresa brasileira Solverde, maior distribuidora de fibra óptica do país (ZTT, 2015; GONÇALVES, 2015). 
FIGURA 2: LOCALIZAÇÃO DA FÁBRICA ZTT NO MUNICÍPIO DE MARECHAL DEODORO-AL

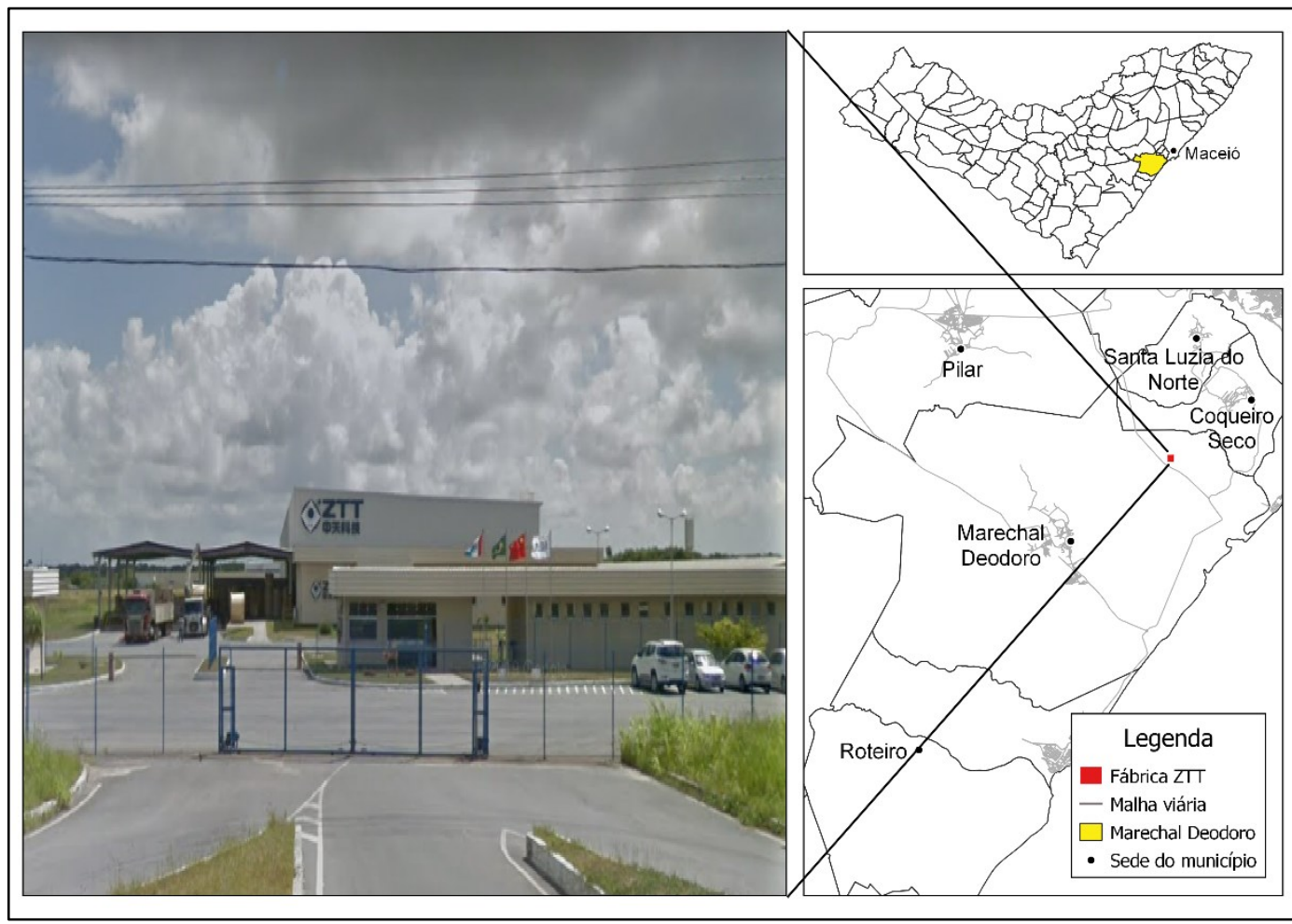

Fonte: Google Imagens. Elaborado pelos autores.

A atração da fábrica para o estado contou com mediação da empresa alagoana de telecomunicações Aloo Telecom. Entre os fatores decisivos para instalação da fábrica, além do programa estadual de incentivos fiscais, o Prodesin, estão a localização estratégica de Alagoas no Nordeste, proximidade ao porto de Suape, em Pernambuco, e a presença da Braskem, fornecendo insumos para produção de cabos (GONÇALVES, 2015).

Outro investimento expressivo de origem chinesa ocorreu em 2020 na aquisição de $30 \%$ da startup alagoana de engenharia pela Concremat, de propriedade da multinacional de engenharia China Communications Construction Company, podendo ser caracterizado como investimento greenfield ${ }^{4}$. A plataforma desenvolvida pela startup é utilizada nos projetos da empresa informatizando os processos e reduzindo o custo de serviços nas diferentes etapas da obra (AGENDAA, 2020).

A presença chinesa em Alagoas se destaca também no setor de comércio. Aproveitando o aumento do consumo das famílias e o consequente crescimento do comércio, multiplicaram lojas de comerciantes chineses em shopping centers e principalmente em regiões de comércio popular das cidades. Geralmente esses estabelecimentos comercializam eletrônicos e utilidades gerais para uso doméstico.

\footnotetext{
${ }^{4}$ Geralmente o investimento greenfield é associado a atividades inovadoras ou em startups em estágio inicial. Segundo o CEBC (2019) este foi o tipo de investimento chinês predominante no Brasil entre 2010 e 2018 com média de $47,5 \%$ no total dos investimentos, seguido por fusões e aquisições e joint venture.
} 
A melhoria das finanças públicas também favoreceu a atração de investimentos privados, uma vez que melhorou a capacidade de contrapartida do estado através do investimento em infraestrutura. Mudanças na contabilidade da dívida como a redução da taxa de juros, alteração de indexador e alongamento do pagamento das parcelas aliado a melhoria na capacidade de arrecadação, reduziram a dívida em R $\$ 2$ bilhões. Isto é verificado quando comparamos o total das despesas e receitas do estado entre 2010 e 2019, quando o saldo subiu de R 85 milhões para R \$3,3 bilhões. Contornando um antigo problema do estado, o alto endividamento e a limitada capacidade de investimento (CARVALHO, 2019; SICONFI, 2021).

O fortalecimento das relações econômicas com a China e divergências políticas entre os governadores do Nordeste e o Governo Federal repercutiram na esfera político-institucional. Em 2019, é criado o Consórcio Nordeste com adesão de todos os estados da região, justamente numa conjuntura política desfavorável aos interesses da região. Segundo Clementino (2019) o consórcio público tem a possibilidade de efetivação de pactos territoriais que facilitem as relações intergovernamentais, e no caso do Consórcio Nordeste, entre seus objetivos estão o fortalecimento regional e o desenvolvimento com justiça e inclusão social. Tornando-se uma alternativa para minimizar a burocracia e promover uma política colaborativa entre os governos estaduais da região.

Ainda em 2019, diante da paralisia dos investimentos do Governo Federal, diversos governadores dos estados brasileiros viajaram à China em busca de investimentos para movimentar as economias estaduais. Nesse movimento, houve participação do governo de Alagoas, anunciando o início das negociações para instalação da indústria de malte GDH Supertime Malting, que pretende vender o produto às cervejarias do Nordeste, e da fabricante de fibra de vidros CPIC, com objetivo de atender ao mercado regional e servir de plataforma de exportação (CARVALHO e ALVES, 2019).

Durante a busca do governo alagoano por investimentos chineses, a fabricante de embalagens longa-vida GSPak, anunciou investimento de R \$ 187 milhões na instalação da fábrica no município de Rio Largo. Sendo concretizado, será o maior investimento chinês no estado nos últimos anos (CARVALHO e ALVES, 2019).

Entretanto, é necessário abrir um breve parêntese. Após 2019, o mundo vem enfrentando a maior pandemia do século impactando toda a economia mundial, que aliada as indefinições de uma agenda econômica por parte do Governo Federal e sua condução no cenário pandêmico, tem travado o ambiente para novos investimentos. Diante disso, é incerto afirmar se tais investimentos em Alagoas serão postergados ou mesmo cancelados.

\section{CONCLUSÃO}


Podemos concluir que o fortalecimento das relações econômicas a nível Brasil-China, repercutiu em Alagoas, sobretudo, no aumento de importação de produtos chineses pelo estado, comandada por produtos de média-baixa intensidade tecnológica, condizente às características socioeconômicas do estado.

O ritmo de crescimento das importações oriundas da China acompanhou os anos de maior crescimento da economia estadual, mostrando que parte desse crescimento extrapolou o mercado interno. Na última década o país se tornou o maior parceiro comercial de Alagoas pela via da importação e iniciou investimentos no setor industrial, movimento que aliado ao baixo crescimento das economias europeias e norte-americana no pós-crise de 2008, tem alçado a China como importante fonte de financiamento nos últimos anos.

O destaque chinês nas importações estaduais e a maior variedade no portfólio dos produtos não foi acompanhado pelas exportações, onde Alagoas mantém como principais destinos, parceiros tradicionais, Europa e Estados Unidos, indicando a necessidade de diversificação econômica, inclusive no setor agrícola, de modo a aproveitar o fortalecimento das relações econômicas e estimular a pauta de exportações alagoanas destinadas à China.

Considerando o recorte temporal da pesquisa de 2003 a 2019, devem ser feitos outros estudos sobre os impactos nas relações econômicas entre Alagoas e China após a pandemia mundial do Covid19; estudos que apontem possibilidades para o estado de Alagoas estimular sua exportação com destino à China; ou até mesmo, estudos que relacionem a dinâmica das relações econômicas AlagoasChina ao contexto geopolítico de disputa tecnológica e econômica entre os Estados Unidos e a China.

\section{REFERÊNCIAS}

AGENDAA. Uma das mais tradicionais empresas de engenharia no Brasil compra $30 \%$ de startup alagoana. AgendaA, Maceió, 15 jun. 2020. Disponível em: http://www.agendaa.com.br/negocios/gente-e-gesto/8393/2020/06/15/uma-das-mais-tradicionaisempresas-de-engenharia-no-brasil-compra-30-de-startup-alagoana. Acesso em: 17 jan. 2021.

ALAGOAS. Secretaria do Planejamento, Gestão e Patrimônio. Alagoas em números. Maceió, 2016. Disponível em: https://dados.al.gov.br/catalogo/dataset/alagoas-em-numeros/resource/64faf747e70a-451f-8c74-c4984801e43b. Acesso em: 19 dez. 2020.

ALAGOAS. Secretaria do Planejamento, Gestão e Patrimônio. Anuário Estatístico do Estado de Alagoas-2017. Maceió, v. 24, 2018.

APMC - Administração do Porto de Maceió. Instrução APMC n 048/2018, de 27 de novembro de 2018. Maceió: APMC, 27 nov. 2018. Disponível em: http://www.portodemaceio.com.br/portal/arquivos/regulamentos/inst_0482018.pdf. Acesso em: 07 jan. 2021.

BECARD, Danielly Silva Ramos. O que esperar das relações Brasil-China?. Revista de Sociologia e Política, Curitiba, v. 19, n. suplementar, p. 31-44, nov. 2011. 
BRASIL. Ministério da Economia. Exportação e importação: municípios. Brasília, 2020. Disponível em: http://comexstat.mdic.gov.br/pt/municipio. Acesso em: 02 dez. 2020.

CARVALHO, Cícero Péricles de. Alagoas: 2000-2018. Revista Conjuntura Econômica, Fortaleza, edição especial, p. 345-357, 2019.

CARVALHO, Cícero Péricles de. Os impactos da epidemia na economia alagoana: notas sobre a conjuntura econômica nos meses de março a junho de 2020. Maceió: Faculdade de Economia, Administração e Contabilidade da Universidade Federal de Alagoas, 2020. 51p. (Análise da conjuntura econômica de Alagoas).

CARVALHO, Severino; ALVES, Andressa. Mais duas empresas chinesas estudam investir em Alagoas. Agência Alagoas, Maceió, 29 jul. 2019. Disponível em: http://agenciaalagoas.al.gov.br/noticia/item/30558-mais-duas-empresas-chinesas-estudam-investirem-alagoas. Acesso em: 17 jan. 2021.

CHANG, Ha-Joon. Chutando a escada: a estratégia do desenvolvimento em perspectiva histórica. São Paulo: Unesp, 2004.

CLEMENTINO, Maria do Livramento Miranda. A atualidade e o ineditismo do Consórcio Nordeste. Boletim regional, urbano e ambiental, Brasília, n. 21, p. 165-174, jul./dez. 2019.

CNI - Confederação Nacional da Indústria. Perfil da indústria nos estados. 2018. Disponível em: https://perfildaindustria.portaldaindustria.com.br/estado/al. Acesso em: 06 jan. 2021.

JABBOUR, Elias M. K. Projeto nacional, desenvolvimento e socialismo de mercado na China de hoje. 2010. Tese (Doutorado em Geografia) - Faculdade de Filosofia, Letras e Ciências Humanas, Universidade de São Paulo, São Paulo, 2010.

JABBOUR, Elias M. K. China: socialismo e desenvolvimento sete décadas depois. São Paulo: Anita Garibaldi; Fundação Maurício Grabois, 2019.

EXAME. China reduz tarifa para açúcar e Brasil pode ampliar exportações. Exame, São Paulo, 22 maio 2020. Disponível em: https://exame.com/economia/china-reduz-tarifa-para-acucar-e-brasilpode-ampliar-exportacoes. Acesso em: 06 jan. 2021.

FIEA - Federação das Indústrias do Estado de Alagoas. Zoneamento Industrial em Alagoas. Maceió: Fiea, 2014. Disponível em: http://www.al.senai.br/public/documentos/zoneamentoindustrial.pdf. Acesso em: 20 dez. 2020.

GONÇALVES, Maurício. ZTT enumera escolha por Alagoas. Gazeta de Alagoas, Maceió, 25 out. 2015. Disponível em: http:/gazetaweb.globo.com/gazetadealagoas/noticia.php?c=275679. Acesso em: 15 jan. 2021.

IBGE - Instituto Brasileiro de Geografia e Estatística. População residente, por sexo, situação e grupos de idade. 2010. Disponível em: https://sidra.ibge.gov.br/tabela/200. Acesso em: 14 dez. 2020.

IBGE - Instituto Brasileiro de Geografia e Estatística. Sistema de Contas Regionais. 2018. Disponível em: https://www.ibge.gov.br/estatisticas/economicas/contas-nacionais/9054-contasregionais-do-brasil.html?=\&t=resultados. Acesso em: 17 dez. 2020.

IPEA - Instituto de Pesquisa Econômica Aplicada. Taxa de câmbio nominal. Brasília, 2021. Disponível em: http://ipeadata.gov.br/exibeserie.aspx?serid=38389. Acesso em: 17 dez. 2020.

LIMA, Ronaldo. Produtores alagoanos apostam na excelente fertilidade da soja para a safra 2019/2020. Agência Alagoas, Maceió, 08 out. 2019. Disponível em: 
http://www.agenciaalagoas.al.gov.br/noticia/item/31226-produtores-alagoanos-apostam-naexcelente-fertilidade-da-soja-para-a-safra-2019-2020. Acesso em: 06 jan. 2021.

MAMIGONIAN, Armen. O mundo no final do século XX e início do século XXI. Boletim Paulista de Geografia, São Paulo, v. 100, p. 173-205, 2018.

MENDES, Hinckley Wendell do Nascimento. A indústria de alimentos em Alagoas e a formação dos mercados de Maceió e Arapiraca. 2020. Dissertação (Mestrado em Geografia) - Instituto de Geografia, Desenvolvimento e Meio Ambiente, Universidade Federal de Alagoas, Maceió, 2020.

RUEDA, Fernando Galindo; VERGER, Fabien. OECD Taxonomy of Economic Activities Based on R\&D Intensity. OECD Science, Technology and Industry Working Papers, Paris, n. 4, p. 3-25, 2016.

SINCONFI - Sistema de Informações Contábeis e Fiscais do Setor Público Brasileiro. Cadastro de operações de crédito - Alagoas. Brasília, 2021. Disponível em: https://siconfi.tesouro.gov.br/siconfi/pages/public/declaracoes_anteriores/declaracoes_anteriores_lis t.jsf. Acesso em: 17 jan. 2021.

ZTT. ZTT inaugura em Alagoas sua primeira fábrica. Maceió, 2015. Disponível em: https://www.zttcable.com.br/ztt-inaugura-em-alagoas-sua-primeira-fabrica-no-brasil. Acesso em: 15 jan. 2021. 